\title{
Penegakan Hukum Administrasi Terhadap Ketidakpatuhan AMDAL
}

\author{
Bagus Setiawan Hardono $^{1^{*}}$; Nasrullah $^{2}$; Beni Hidayat ${ }^{3}$ \\ ${ }^{1,2,3}$ Program Studi Hukum, Fakultas Hukum, Universitas Muhammadiyah Yogyakarta, Indonesia \\ *Korespondensi: bagus.setiawan.2013@law.umy.ac.id
}

\section{Info Artikel}

Diajukan: 25-10-2020

Direview: 16-11-2020

Direvisi: $28-11-2020$

Diterima: 25-12-2020

DOI: $10.18196 / \mathrm{mls} . v 2 i 1.11481$

\begin{abstract}
Abstrak
Hukum merupakan perangkat untuk mengatur dan memuat sanksi bagi pelanggarnya. Demikian juga pentingnya kehadiran hukum yang jelas dan tegas dalam masalah lingkungan merupakan faktor kuat dalam mendorong penegakan hukum lingkungan di Indonesia. Dengan penerapan hukum yang baik diharapkan bisa memberi efek jera terhadap pelanggar agar supaya tercipta lingkungan yang baik bagi kepentingan bersama. Dalam permasalahan
\end{abstract}

lingkungan diatur bahwa setiap kegiatan/usaha harus membuat izin lingkungan sebelum melaksanakan kegiatan/usahanya. Tujuan penelitian ini adalah untuk mengetahui bagaimana penegakan Hukum Administrasi dalam hal kewajiban Analisis Mengenai Dampak Lingkungan (AMDAL) di Kota Yogyakarta dan kendala dalam penegakan Hukum Administrasi dalam hal Analisis Mengenai Dampak Lingkungan. Penelitian masuk dalam tipologi penelitian hukum empiris. Data penelitian dikumpulkan dengan cara studi pustaka dan wawancara, kemudian diolah menjadi bentuk deskripsi analisis. Dari penelitian ini didapatkan bahwa pemerintah Kota Yogyakarta dalam penegakan hukum perihal AMDAL lebih mengupayakan penegakan hukum yang bersifat prefentif dibandingkan upaya represif. Hal ini dilakukan untuk menjaga stabilitas ekonomi yang ada di Kota Yogyakarta. Adapun kendala dalam penegakan hukumnya adalah kendala yang bersifat yuridis yaitu peraturan yang terlalu banyak hingga membuat pelaku usaha/pemrakarsa kesulitan dalam pembuatan izin lingkungan. Selain itu, masyarakat yang belum memahami pentingnya menjaga dan melestarikan lingkungan membuat banyak kegiatan atau usaha yang mendatangkan dampak buruk bagi lingkungan.

Kata kunci: AMDAL, izin lingkungan, penegakan hukum

\section{Pendahuluan}

Pembangunan infrastruktur di setiap daerah memberikan dampak positif dan negatif terhadap masyarakat dan lingkungan. Dengan adanya pembangunan bisa menunjang perekonomian dan dapat memenuhi barang dan jasa yang dibutuhkan masyarakat setempat. Sebagai contoh, untuk daerah yang mengoptimalkan pembangunan wisata maka diperlukan sarana-sarana penunjang seperti tempat penginapan, hotel dan jalan yang baik untuk kenyamanan wisatawan datang berkunjung ke daerah tersebut. Dengan adanya pembangunan di sektor industri juga bisa lebih mengoptimalkan pengolahan bahan mentah yang ada dalam suatu daerah demi dan untuk masyarakat daerah tersebut. Sebab sektor-sektor industri, bisa memanfaatkan bahan-bahan mentah tersebut supaya kegunaannya menjadi lebih besar.

Setiap aspek pembangunan akan memberikan dampak yang signifikan bagi lingkungan hidup. Limbah yang dihasilkan industri dapat menimbulkan kerusakan lingkungan yang nantinya bisa berdampak pada masyarakat sekitar. Pengolahan limbah industri yang buruk dapat menimbulkan pencemaran lingkungan. Akibatnya, warga yang tinggal di lingkungan sekitar akan ikut tercemar dan terserang berbagai macam penyakit. Tak hanya masyarakat, hewan dan 
tumbuhan pun akan ikut terpapar dampak buruk polusi dari industri. Namun dengan pengaturan dan pengolahan limbah yang tepat akan mengurangi dampak negatif ini. ${ }^{1}$

Menurut Muchammad Taufiq tujuan pengelolaan lingkungan dilakukan untuk mencegah dampak negatif, menanggulangi dan mengendalikan dampak negatif yang timbul dan meningkatkan dampak positif sehingga dampak tersebut memberikan manfaat yang besar. ${ }^{2}$

Negara berkembang, berkenaan dengan pengelolaan sumber daya lingkungan hidup menggunakan paradigma yang menghendaki adanya suatu kebebasan dalam "mengeksploitasi" sumber daya alam yang dimiliki. Dalam paradigma negara berkembang pembangunan (development) hanya dapat dilakukan dengan memanfaatkan sumber daya alam. ${ }^{3}$ Untuk mencegah eksploitasi yang berlebihan, diaturlah mengenai pembangunan dan lingkungan hidup dalam undang-undang. Adapun definisi lingkungan hidup menurut Munadjat Danusaputro adalah semua benda dan kondisi, termasuk di dalamnya manusia dan tingkah perbuatannya, yang terdapat dalam ruang tempat manusia berada dan mempengaruhi hidup serta kesejahteraan manusia dan lainnya. ${ }^{4}$

Kota Yogyakarta sebagai kota yang terus mengalami perkembangan, baik dilihat dari segi aktivitas maupun jumlah penduduknya, mengharuskan adanya pembangunan yang menunjang kebutuhan masyarakat dan daerah. Pertambahan jumlah penduduk yang terjadi juga secara tidak langsung memberi dampak bagi pertambahan sarana dan prasarana akibat perkembangan kebutuhan penduduk kota. Perkembangan nenicu maraknya pembangunan di Yogyakarta khususnya pembangunan di sektor pariwisata seperti hotel dan penginapan bagi wisatawan yang berkunjung. Hal ini memberi implikasi bagi semakin berkurangnya ruang terbuka hijau di Kota Yogyakarta. Apalagi setelah adanya kebijakan Aglomerasi Perkotaan Yogyakarta (APY) di Kota Yogyakarta yang berdampak bagi semakin meluasnya kawasan permukiman, komersial, dan berkembanganya jalur transportasi. Dengan adanya kebijakan ini akan memacu maraknya bangunan-bangunan tinggi seperti hotel bertingkat dan pusat perbelanjaan untuk tujan aglomerasi perkotaan.

Menurut pandangan Pengurangan Risiko Bencana (PRB), bangunan tinggi ini membuat risiko bencana semakin tinggi. Forum PRB menyebutkan ada tiga bencana yang muncul akibat pembangunan, yakni bencana banjir, krisis air, dan konflik sosial. Di Yogyakarta, beberapa ancaman bencana itu sudah terbukti. Bangunan tinggi, yang didominasi hotel dan apartemen, membuat sumur warga kering akibat perebutan sumber air. Kasus ini terjadi pada Fave Hotel di Miliran dan hotel 101 di Gowongan - keduanya di Kota Yogyakarta. Dalam kasus Fave Hotel, puluhan sumur warga mengering akibat perebutan air tanah antara warga dan hotel. Sedangkan di hotel 101 ada lebih dari 35 kepala keluarga kesulitan air akibat sumur mengering. Eko Teguh Paripurno, peneliti Penanggulangan Bencana dari Universitas Pembangunan Nasional

1 Redaksi, “14 Dampak Pembangunan Terhadap Lingkungan yang Wajib Diketahui”, https://materiips.com/dampak-pembangunan-terhadap-lingkungan, Diakses pada $10 \mathrm{Juli}$ 2019, pukul 13.31 WIB.

${ }^{2}$ Muchammad Taufiq, 2011, "Kedudukan dan Prosedur AMDAL dalam Pengelolaan Lingkngan Hidup", Jurnal WIGA No, 2088-0944. Lumajang.

${ }^{3}$ Mukhlish dan Mustafa Lutfi, 2010, Hukum Administrasi Lingkungan Kontemporer, Setara Press, Malang, h. 6.

${ }^{4}$ Nasrullah, 2015, "Hukum Lingkungan", http://repository.umy.ac.id/bitstream/handle/123456789/4060/HUKUM\%20LINGKUNGAN.pdf?sequenc e=1\&isAllowed=y, diakses pada 1 Juli 2020, pukul 20.30 WIB. 
Yogyakarta, melakukan riset terkait dampak pembangunan hotel di Yogyakarta terhadap krisis air. Hasilnya, sejak 2006, permukaan air tanah terus menurun 15-50 sentimeter per tahun. Akibatnya, warga Yogyakarta semakin susah menjangkau air tanah. ${ }^{5}$

Pemerintah melalui peraturan daerah dan penegakan Hukum Administrasi perihal Analisis Mengenai Dampak Lingkungan (AMDAL) harus hadir untuk meminimalisir dan mengurangi dampak buruk dari setiap pembangunan kepada lingkungan dan masyarakat. Hukum administrasi seperti yang dijelaskan oleh Prajudi Atmosudirjo adalah hukum mengenai administrasi negara dan hukum hasil ciptaan administrasi negara. ${ }^{6}$ Berdasarkan pada penjelasan tersebut, maka terdapat sebuah pemahaman yang cukup luas bahwa hukum administrasi negara terdiri dari beberapa kombinasi yaitu: ${ }^{7}$

1) adanya suatu tata pemerintahan (bestuur; government/ administration);

2) tata usaha negara (birokrasi; bureaucracy);

3) administrasi rumah tangga negara;

4) administrasi pembangunan; dan

5) administrasi lingkungan.

Dilain pihak, Girindro Pringgodigdo mengatakan bahwa selain pengertian yang luas dari administrasi negara, terdapat beberapa pengertian yakni; (a) sebagai aparatur negara, aparatur pemerintah atau sebagai institusi politik (kenegaraan), (b) sebagai aktivitas melayani pemerintah, yakni sebagai pemerintahan operasional, dan (c) sebagai proses teknis penyelenggaraan undang-undang. ${ }^{8}$

Berdasarkan pengertian-pengertian tersebut, dapat disimpulkan bahwa lapangan dari hukum administrasi negara terdiri dari beberapa kelompok yaitu:

1) Hukum pemerintahan (bestuursrecht);

2) Hukum Peradilan (justitierecht), yang meliputi lembaga peradlan, yakni:
a. Peradilan Ketatanegaraan,
b. Peradilan Tata Usaha Negara,
c. Peradilan Pidana, dan
d. Peradilan Perdata.

3) Hukum Kepolisian (politierecht);

\footnotetext{
5 Mawa Kresna, 2017, "Resiko dan Nasib Buruk Pembangungan Hotel di Yogyakarta", https://tirto.id/risiko-dan-nasib-buruk-pembangunan-hotel-di-yogyakarta-bkWg. Diakses pada 10 Juni 2019 pukul 20.10 WIB.

6 Prajudi Atmosurdirjo, 1988, Hukum Administrasi Negara, Seri Pustaka ilmu Administrasi,Ghalia Indonesia, Jakarta, h. 42

${ }^{7}$ Muklish dan Mustafa Lutfi, 2010, Hukum Administrasi Lingkungan Kontemporer, Setara Press, Malang. h., 20

${ }^{8}$ Hendra Nurtjahyo, 2004, Politik Hukum Tata Negara Indonesia, Pusat Studi Hukum Fakultas Hukum Universitas Indonesia, Jakarta, h. 186
} 


\section{4) Hukum Perundang-undangan (regelaarsrecht $)^{9}$}

Saat ini Indonesia khususnya Kota Yogyakarta sedang mengalami proses percepatan pembangunan lewat program-program pemerintah. Hal ini dilakukan untuk mengejar ketertinggalan kemajuan dengan daerah-daerah yang lain. Di sisi lain pembangunan itu mengakibatkan sumberdaya bumi harus digunakan semaksimal mungkin. Hal tersebut tentunya mengakibatkan timbulnya permasalahan-permasalahan lingkungan. Oleh karena itu, optimalisasi sumberdaya alam harus digunakan sebijak mungkin. ${ }^{10}$

Hukum merupakan perangkat untuk mengatur dan memuat sanksi bagi pelanggarnya. Demikian juga pentingnya kehadiran hukum yang jelas dan tegas dalam masalah lingkungan merupakan faktor kuat dalam mendorong penegakan hukum lingkugan di Indonesia. Dengan diterapkannya hukum diharapkan bisa memberi efek jera terhadap pelanggar agar supaya tercipta lingkungan yang baik bagi kepentingan bersama. AMDAL sebagai salah satu bentuk kajian lingkungan memiliki peran strategis dalam pengelolaan setiap kegiatan pembangunan. Kegiatan pembangunan yang selalu diikuti dampak positip dan dampak negatip, harus dilakukan kajian secara cermat dan komprehensif, agar dapat dimaksimalkan dampak positip dan diminimumkan dampak negatip. Regulasi lingkungan yang sangat dinamis membutuhkan Guidance (panduan), yang memudahkan bagi mereka yang memahami AMDAL.

Berdasarkan pemaparan diatas peneliti ingin mengkaji tentang bagiamana penegakan hukum administrasi dalam hal kewajiban Analisis Mengenai Dampak Lingkungan (AMDAL) di Kota Yogyakarta dan apa kendala hukum yang dihadapi dalam penegakan hukum tersebut. Tulisan ini berupaya mengkaji bagaimana penegakan hukum dalam hal ketidak patuhan AMDAL.

\section{Metode Penelitian}

Penelitian ini menggunakan 2 jenis penelitian hukum, yaitu penelitan hukum empiris dan normatif. Penelitian hukum empiris yaitu penelitian yang berfokus pada perilaku hukum masyarakat. Penelitian ini dilakukan dengan mewawancarai Dinas Lingkungan Hidup Kota Yogyakarta atau dinas terkait untuk mendapatkan data perihal penelitian. Sedangkan penellitian hukum normatif yang berfokus pada mengkaji asas-asas, konsep-konsep hukum, serta peraturan perundang-undangan yang terkait dengan penegakan hukum administrasi dalam hal kewajiban Analisis Mengenai Dampak Lingkungan di Kota Yogyakarta. Sumber data berupa data primer dan sekunder dengan teknik pengumpulannnya berupa wawancara dan studi pustaka.

Data yang diperoleh dalam penelitian ini dianalisis secara kualitatif. Analisis kualitatif yaitu suatu tata cara penelitian yang menghasilkan data deskriptif analisis, yaitu menganalisis, meneliti dan mempelajari secara utuh bahan bahan hukum yang ada serta mengungkapkan fakta-fakta secara mendalam berdasarkan karakteristik ilmiah dari individu atau kelompok untuk memahami dan mengungkap sesuatu dibalik fenomena. ${ }^{11}$

\footnotetext{
${ }^{9}$ Usep Ranawijaya, 1983, Hukum Tata Negara Indonesia Dasar-dasarnya, Ghalia Indonesia, Jakarta, h. 12.

${ }^{10}$ Imam Supardi, 2003, Lingkungan Hidup dan Kelestariannya, Alumni, Bandung, h.. 73

${ }^{11}$ Mukti Fajar ND \& Yulianto Achmad, (2015), Dualisme Penelitian Hukum Normatif \& Empiris,

Penerbit Pustaka Pelajar, Yogyakarta, h.192.
} 


\section{Hasil dan Pembahasan}

\subsection{Dinas Lingkungan Hidup Kota Yogyakarta}

Dinas Lingkungan Hidup Kota Yogyakarta bertempat di Jl. Sultan Agung No.133, Gunungketur, Pakualaman, Kota Yogyakarta, Daerah Istimewa Yogyakarta 55166. Dalam hal menjalankan tugas Dinas Lingkan Hidup mengacu pada visi sebagai Institusi yang handal dalam pengelolaan lingkungan hidup untuk mewujudkan masyarakat Kota Yogyakarta yang berbudaya dan berwawasan lingkungan.

Dalam hal mencapai visi tersebut Dinas Lingkungan Hidup Kota Yogyakarta mengacu pada misi yaitu sebagai berikut:

a. Mewujudkan peningkatan kualitas lingkungan dalam rangka pelestarian fungsi lingkungan hidup dengan mengikutsertakan dunia usaha, masyarakat dan sekolah dalam pengelolaan lingkungan.

b. Mewujudkan Ruang Terbuka Hijau kawasan perkotaan yang memenuhi fungsi ekologis, fungsi estetis, fungsi sosial dan nyaman.

c. Mewujudkan tatakelola kebersihan dan pengelolaan persampahan yang berkualitas

Adapun tujuan dari Dinas Lingkungan Hidup Kota Yogyakarta adalah:

a. Meningkatkan pengawasan dan pemulihan kualitas lingkungan hidup sesuai daya dukung dan daya tampung lingkungan dalam rangka pelestarian lingkungan hidup.

b. Mengembangkan kapasitas sumber daya lingkungan hidup secara optimal.

C. Meningkatkan penyediaan dan pengelolaan taman kota dan perindang jalan.

d. Meningkatkan kebersihan kota dan kinerja pengelolaan sampah.

Dalam menjalankan visi dan misi tersebut Dinas Lingkungan Hidup Kota Yogyakarta membuat struktur organisasi yang tersaji pada gambar 1

Gambar 1. Bagan Organisasi Dinas Lingkungan Hidup Kota Yogyakarta.

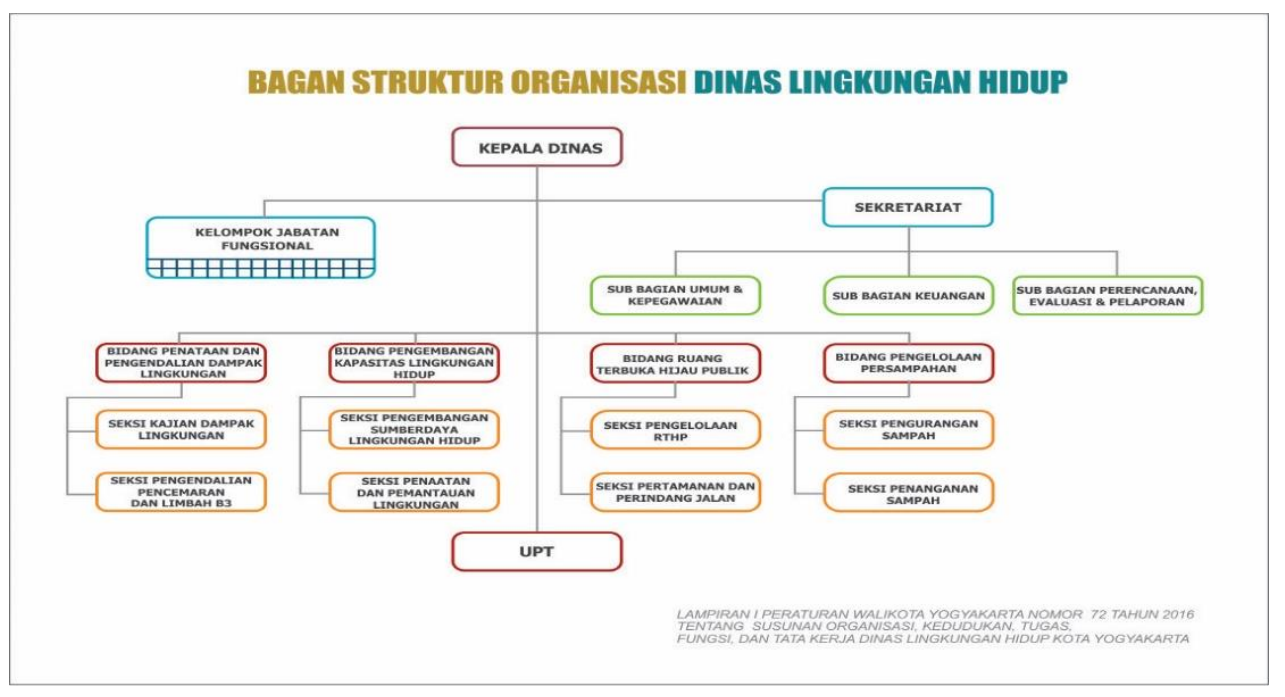

Sumber: Dinas Lingkungan Hidup Kota Yogyakarta 
Hal ini dilakukan untuk mempermudah kinerja Dinas Lingkungan Hidup serta membagi tugas dan kewenangan kepada pejabat di Dinas Lingkungan Hidup Kota Yogyakarta.

\subsection{Penegakan Hukum Administrasi dalam hal Kewajiban Analisis Mengenai Dampak Lingkungan di Kota Yogyakarta}

Upaya pengelolaan lingkungan hidup dimanifestasikan melalui adanya Undangundang Nomor 4 Tahun 1982 Tentang Ketentuan-Ketentuan Pokok Pengelolaan Lingkungan Hidup dan dirubah menjadi Undang-undang Nomor 23 tahun 1997 yang selanjutnya dinyatakan tidak berlaku oleh Undang-undang No. 32 Tahun 2009 tentang Perlindungan dan Pengelolaan Lingkungan Hidup.

Meningkatnya kompleksitas permasalahan lingkungan yang ada membuat undang-undang terdahulu belum bisa memberikan kepastian hukum untuk masyarakat. Ada beberapa dasar pertimbangan yang menjadi dasar diberlakukannya UU PLH 2009 antara lain sebagai berikut:

a. bahwa lingkungan hidup yang baik dan sehat merupakan hak asasi setiap warga negara Indonesia sebagaimana diamanatkan dalam Pasal 28H Undang-Undang Dasar Negara Republik Indonesia Tahun 1945;

b. pembangunan ekonomi nasional sebagaimana diamanatkan oleh UUD diselenggarakan berdasarkan prinsip pembangunan berkelanjutan dan berwawasan lingkungan;

c. bahwa semangat otonomi daerag dalam penyelenggaraan pemerintahan telah membawa perubahan hubungan dan kewenangan antara Pemerintah pusat dan pemerintah daerah, termasuk dalam bidang perlindungan dan pengelolaan lingkungan hidup;

d. bahwa kualitas lingkungan hidup yang semakin menurun telah mengancam kelangsungan perikehidupan manusia dan makhluk hidup lainnya sehingga perlu dilakukan perlindungan dan pengelolaan lingkungan hidup yang sungguh-sungguh dan konsisten oleh semua pemangku kepentingan;

e. bahwa pemanasan global yang semakin meningkat mengakibatkan perubahan iklim sehingga memperparah penurunan kualitas lingkungan hidup karena itu perlu dilakukan perlindungan dan pengelolaan lingkungan hidup;

f. bahwa agar lebih menjamin kepastian hukum dan memberikan perlindungan terhadap hak setiap orang untuk mendapatkan lingkungan hidup yang baik dan sehat sebagai bagian dari perlindungan terhadap keselamatan ekosistem, perlu dilakukan pembaruan terhadap Undang-undang Nomor 23 Tahun 1997 tentang Pengelolaan Lingkungan Hidup;

g. bahwa berdasarkan pertimbangan sebagaimana dimaksud dalam huruf a, huruf b, huruf c, huruf d, huruf e, dan huruf f, perlu membentuk Undang-undang tentang Perlindungan dan Pengelolaan Lingkungan Hidup.

Pemerintah daerah yang merupakan sub-sistem dari sistem penyelenggaraan pemerintahan nasional memiliki kewenangan untuk mengatur dan mengurus rumah tangganya sendiri khususnya mengenai pembangunan serta izin pembangunan terkait di pemerintahannya untuk mencegah kerusakan lingkungan di daerah tersebut.

Dalam penyelenggaraan pemerintahan di Indonesia, didasarkan pada asas penyelenggaraan pemerintahan daerah. Secara umum asas penyelenggaraan pemerintahan daerah di Indonesia terdiri dari; asas dekonsentrasi, asas desentralisasi dan asas tugas 
pembantuan. ${ }^{12}$ Sebagai penyelenggara otonomi daerah, pemerintahan daerah mempunyai kewenangan bertindak untuk kepentingan daerahnya.

Pemerintah daerah bertanggungjawab atas pemberian izin AMDAL terhadap pihak-pihak yang sedang atau berencana mendirikan bangunan yang ada diwilayahnya. Hal ini tertuang dalam Pasal 63 ayat (3) UU Nomor 32 tahun 2009 yang menyatakan bahwa dalam hal perlindungan dan pengelolaan lingkungan hidup, pemerintah kabupaten/kota bertugas dan berwenang:

a. menetapkan kebijakan tingkat kabupaten/kota;

b. menetapkan dan melaksanakan KLHS tingkat kabupaten/kota;

c. menetapkan dan melaksanakan kebijakan mengenai RPPLH kabupaten/kota;

d. menetapkan dan melaksanakan kebijakan mengenai AMDAL dan UKL-UPL;

e. menyelenggarakan inventarisasi sumberdaya alam dan emisi gas rumah kaca pada tingkat kabupaten/kota;

f. mengembangkan dan melaksanakan kerjasama dan kemitrtaan, instrumen lingkungan hidup;

g. memfasilitasi penyelesaian sengketa;

h. melakukan pembinaan dan pengawasan ketaatan penanggung jawab usaha dan/atau kegiatan terhadap ketentuan perizinan lingkungan dan peraturan perundang-undangan;

i. melaksanakan pelayanan standar minimal;

j. melaksanakan kebijakan megenai tata cara pengakuan keberadaan masyarakat hukum adat, kearifan lokal, dan hak masyarakat hukum adat yang terkait dengan perlindungan dan pengelolaan lingkungan hidup pada tingkat kabupaten/kota;

k. mengelola informasi lingkungan hidup tingkat kabupaten/kota;

1. mengembangkan dan melaksanakan kebijakan sistem informasi lingkungan hidup tingkat kabupaten kota;

m. memberikan pendidikan, pelatihan, pembinaan, dan penghargaan;

n. menerbitkan izin lingkungan pada tingkat kabupaten/kota;

o. melakukan penegakan hukum lingkungan pada tingkat kabupaten/kota.

Dinas Lingkungan Hidup Kota Yogyakarta berfungsi tidak hanya menjadi penegak melaikan sebagai pintu pertama dalam pencegahan kerusakan lingkungan yang ada di Yogyakarta. Meskipun pembangunan yang ada atau jenis usaha yang ada tidak termasuk wajib AMDAL, akan tetapi harus memiliki dokumen UPL dan UKL seperti yang diatur oleh Pemerintah Daerah Istimewa Yogyakarta didalam Peraturan Gurbenur Daerah Istimewa Yogyakarta No 7 Tahun 2013 tentang Usaha dan/ Kegiatan Wajib Upaya Pengelolaan Lingkungan Hidup dan Upaya Pemantauan Lingkungan Hidup.

\footnotetext{
${ }^{12}$ Dr. H. Rahyunir Rauf, M.Si, 2017, "Perubahan Kedudukan Kelurahan Dari Perangkat Daerah Menjadi Perangkat Kecamatan”, WEDANA, Volume III, Nomor 1, Riau. h. 225.
} 
Dalam upaya untuk mengetahui bagaimana penegakan hukum administrasi dalam hal kewajiban Analisis Mengenai Dampak Lingkungan di Kota Yogyakarta, penulis melakukan wawancara ke Dinas Lingkungan Hidup Kota Yogyakarta khususnya pada bidang PPDL dan bidang melalui Bidang Penataan, Pengkajian, dan Pengembangan Kapasitas Lingkungan Hidup seksi Penaatan dan Penegakan Hukum Lingkungan Hidup. Dalam wawancara tersebut dijelaskan bahwa bidang PPDL bertugas sebagai pintu pertama dalam pencegahan kerusakan lingkungan yang timbul akibat pembangunan atau kegiatan usaha melalui pemeriksaan izin lingkungan yang ada sedangkan seksi PPHLH bertugas sebagai pengevaluasi izin yang telah diberikan sekaligus memberikan sanksi terhadap pelaku kegiatan yang melanggar izin yang telah disepakati.

Dinas Lingkungan Hidup Kota Yogyakarta menjelaskan bahwa Kota Yogyakarta telah mempunyai Peraturan Daerah Nomor 1 tahun 2015 tentang Rencana Detail Tata Ruang dan Peraturan Zonasi Kota Yogyakarta Tahun 2015 - 2035 sehingga setiap pelaku usaha atau pemrakarsa tidak dibebankan AMDAL melainkan UKL-UPL. Hal ini selaras dengan pasal 3 Peraturan Gubernur Daerah Istimewa Yogyakarta Nomor 7 tahun 2003 tentang Usaha dan/atau Kegiatan Wajib Upaya Pengelolaan Lingkungan Hidup dan Upaya Pemantauan Lingkungan Hidup yang menjelaskan bahwa:

a. Usaha dan/atau kegiatan yang berlokasi di kawasan industri yang telah dilengkapi dengan studi AMDAL wajib menyusun UKL-UPL mendasarkan RKL-RPL AMDAL kawasan.

b. Untuk kegiatan berdampak penting terhadap lingkungan hidup dikecualikan dari kewajiban menyusun dokumen AMDAL dan diwajibkan menyusun dokumen UKL-UPL apabila:

1) lokasi rencana usaha dan/atau kegiatannya berada di kawasan yang telah memiliki AMDAL kawasan;

2) rencana usaha dan/atau kegiatannya berada pada kabupaten/kota yang telah memiliki rencana detil tata ruang kabupaten/kota dan/atau rencana tata ruang kawasan strategis kabupaten/kota setelah diketahui kapasitas daya dukung dan daya tampung lingkungan berdasarkan hasil kajian lingkungan hidup strategis; atau

3) usaha dan/atau kegiatannya dilakukan dalam rangka tanggap darurat bencana.

Hal ini selaras dengan yang dijelaskan dalam Peraturan Pemerintah No. 27 Tahun 1999 tentang Analisis Mengenai Dampak Lingkungan yang menjelaskan bahwa:

1. Usaha dan/atau kegiatan yang akan dibangun di dalam kawasan yang sudah dibuatkan analisis mengenai dampak lingkungan hidup tidak diwajibkan membuat analisis mengenai dampak lingkungan hidup lagi.

2. Usaha dan/atau kegiatan sebagaimana dimaksud pada ayat (1) diwajibkan untuk melakukan pengendalian dampak lingkungan hidup dan perlindungan fungsi lingkungan hidup sesuai dengan rencana pengelolaan lingkungan hidup dan rencana pemantauan lingkungan hidup kawasan.

Adapun kriteria mengenai dampak besar dan penting suatu usaha dan/atau kegiatan terhadap kegiatan lingkungan hidup antara lain:

a. jumlah manusia yang akan terkena dampak;

b. luas wilayah persebaran dampak; 
c. intensitas dan lamanya dampak beralangsung;

d. banyaknya komponen lingkungan lainnya yang terkena dampak;

e. sifat kumulatif dampak;

f. berbalik (reversible) atau tidak berbaliknya (irreversible) dampak.

Dalam hal ini untuk segala jenis usaha dan/atau kegiatan usaha yang berdampak penting terhadap lingkungan hidup dikecualikan dari kewajiban menyusun dokumen Amdal dan diwajibkan menyusun dokumen UKL-UPL apabila lokasi rencana usaha dan/atau kegiatannya berada di kawasan yang telah memiliki AMDAL kawasan, rencana usaha dan/atau kegiatannya berada pada Kabupaten/kota yang telah memiliki rencana detail tata ruang kabupaten/kota dan/atau rencana tata ruang kawasan strategis kabupaten/kota setelah diketahui kapasitas daya dukung dan daya tampung lingkungan berdasarkan hasil kajian lingkungan hidup strategis, atau usaha dan/atau kegiatannya dilakukan dalam rangka tanggap darurat bencana.

Berkenaan dengan AMDAL pemerintah Kota Yogyakarta telah mempermudah pemrakarsa untuk melakukan pembangunan atau kegiatan usaha yang ada di Kota Yogyakarta. Dalam hal ini, penegakan hukum hanya berkaitan dengan penegakan izin UKL-UPL yang telah dibuat oleh pemrakarsa berkenaan dengan kegiatan yang dilaksanakannya.

Masalah penegakan hukum akan berkaitan dengan berlakunya kaidah hukum di masyarakat. Suatu kaidah hukum berlaku di masyarakat harus memenuhi syarat yuridis, sosiologis dan filosofis. Kaidah hukum berlaku secara yuridis jika penentuannya didasarkan pada kaidah yang lebih tinggi tingkatannya atau bila berbentuk menurut cara yang ditetapkan, berlakunya secara sosiologis apabila kaidah hukum tersebut efektif, artinya kaidah tersebut dapat dipaksakan berlakunya oleh penguasa atau kaidah tadi berlaku karena diterima dan diakui oleh masyarakat, dan kaidah hukum berlaku secara filosofis artinya sesuai dengan cita-cita hukum sebagai nilai positif yang tertinggi. ${ }^{13}$

Undang-undang Nomor 32 Tahun 2009 tentang Perlindungan dan Pengelolaan Lingkungan Hidup, menjelaskan tentang upaya pencegahan dalam rangka pengendalian dampak lingkungan hidup perlu dilaksanakan dengan menggunakan secara maksimal instrumen pengawasan dan perizinan, yang dapat dilakukan oleh pemerintah, pemerintah daerah dan masyarakat. Pengawasan dan perizinin secara khusus dalam pelaksanaan UKL-UPL atau SPPL di Kota Yogyakarta dilakukan oleh Dinas Lingkungan Hidup Kota Yogyakarta sesuai kewenangan sehingga mempunyai konseskuensi bahwa pemrakarsa harus melaporkan hasil pengelolaan dan pemantauan lingkungan setiap 6 (enam) bulan kepada Dinas Lingkungan Hidup Kota Yogyakarta.

Syahdan, menurut ketentuan Undang-undang Perlindungan dan Pengelolaan Lingkungan Hidup tersebut, menteri, gubernur, atau bupati/walikota, dapat mendelegasikan kewenangannya dalam melakukan pengawasan kepada pejabat/instansi teknis yang bertanggungjawab di bidang perlindungan dan pengelolaan lingkungan hidup. Dalam hal ini bidang Penataan dan Pengendalian Dampak Lingkungan (PPDL).

\footnotetext{
13 Soerjono Soekanto dan Mustafa Abdullah, 1980, Sosiologi Hukum dalam Masyarakat, Rajawali, Jakarta, h.. 13.
} 
Dinas Lingkungan Hidup Kota Yogyakarta dalam menjalankan tugasnya berkaitan dengan upaya pencegahan menyerahkan kewenangannya kepada Bidang Penataan dan Pengendalian Dampak Lingkungan (PPDL). Bidang PPDL sendiri mempunyai tugas yaitu untuk membantu Kepala Dinas dalam merumuskan kebijakan, mengkoordinasikan, membina, mengawasi dan mengendalikan program bidang Penataan dan Pengendalian Dampak Lingkungan. Fungsi Bidang PPDL adalah sebagai berikut:

a. Pelaksanaan kebijakan dan penyiapan bahan koordinasi penyusunan program kerja di bidang Penataan dan Pengendalian Dampak Lingkungan;

b. Perencanaan program kegiatan, penyusunan petunjuk teknis dan naskah dinas di bidang Penataan dan Pengendalian Dampak Lingkungan;

c. Pengkoordinasian, pengembangan dan fasilitasi program kerja di bidang Penataan dan Pengendalian Dampak Lingkungan;

d. Pembinaan, pengawasan dan pengendalian program kerja di bidang Penataan dan Pengendalian Dampak Lingkungan; dan

e. Pelaksanaan monitoring, evaluasi, dan pelaporan program kerja di bidang Penataan dan Pengendalian Dampak Lingkungan.

Berdasarkan penelitian yang dilakukan peneliti, berkaitan seperti dijelaskan Imam Supardi bahwa hukum administrasi lingkungan adalah bagian dari pengembangan sebuah teori (ilmu) yang sangat relevan terhadap pemecahan isu hukum yang diangkat, sehingga dapat dipastikan bahwa eksistensi hukum administrasi lingkungan adalah bagian yang tidak terpisahkan dari substansi hukum administrasi negara itu sendiri. Dengan kata lain, hukum administrasi lingkungan adalah hukum yang berhubungan dengan suatu penerbitan, pengendalian, dan pengembangan di bidang lingkungan, maka Dinas Lingkungan Hidup melalui bidang PPDL telah melaksanakan tugasnya untuk sebagai pintu penerbitan dan pengendalian izin lingkungan yang ada di Yogyakarta.

Bidang PPDL melakukan verivikasi berkas izin lingkungan yang diajukan oleh pemrakarsa sebagai pihak yang akan melakukan usaha dan/atau kegiatan sesuai aturan yang ada. Selanjunya bila sudah sesuai skema yang ada, pemrakarsa sudah bisa melakukan usaha dan/atau kegiatatn yang akan dilakukannya. Berikut skema perizinan UKL-UPL yang harus dilengkapi oleh pemrakarsa. Adapun dalam hasil telaah berkas, peneliti menemukan alur permohonan dokumen lingkungan sebagai berikut:

a. Penanggungjawab usaha dan/atau kegiatan usaha melakukan konsultasi ke Dinas Lingkungan Hidup Kota Yogyakarta

b. Penanggungjawab kegiatan usaha mengirim surat permohonan penapisan jenis dokumen lingkungan hidup ke Dinas Lingkungan Hidup Kota Yogyakarta beserta lampiran yang dibutuhkan. Jenis-jenis lampiran yang dibutuhkan adalah;
a. fotocopy KTP penanggungjawab
b. denah lokasi
c. Siteplan
d. denah bangunan
e. surat keterangan rencana tata kota 
f. Izin Mendirikan Bangunan (bagi yang sudah memiliki) dan atau izin kegiatan lainnya yang pernah dimiliki.

c. Dinas Lingkungan Hidup Kota Yogyakarta mengeluarkan surat tanggapan/telaah penapisan beserta sanksi administratif kepada penanggungjawab sebagai jawaban atas surat permohonan.

d. Penanggungjawab menyusun jenis dokumen lingkungan sesuai surat tanggapan/telaah penapisan dan sanksi administrasi yang telah dikeluarkan Dinas Lingkungan Hidup Kota Yogyakarta.

e. Draft penyusunan dokumen lingkungan yang telah disusun penanggunjawab diserahkan ke Dinas Lingkungan Hidup Kota Yogyakarta untuk uji administrasi

f. Jika dokumen sudah dinyatakan lengkap, penanggungjawab kegiatan menggandakan dokumen sebanyak 12 buah sekaligus menyerahkan surat permohonan izin lingkungan ke Dinas Lingkungan Hidup dan akan mendapat bukti tanda terima kelangkapan administrasi.

g. Dinas Lingkungan Hidup Kota Yogyakarta mengumumkan permohonan izin lingkungan terkait usaha dan/atau kegiatan yang diajukan penangunggunjawab paling lama 2 hari kerja sejak DPLH lengkap adminstrasi

h. Dilaksanakan rapat pemeriksaan UKL-UPL bersama pemrakarsa/pelaku usaha, perangkat wilayah di lokasi rencana usaha yang bersangkutan, dan tim pemeriksa dari OPD terkait. Dalam hal ini, Dinas Lingkungan Hidup Kota Yogyakarta memberikan saran, pendapat, dan tanggapan terkait izin usaha yang diajukan oleh pemrakarsa.

i. Saran, pendapat, dan ttanggapan dari tim pemeriksa diterima oleh penanggungjawab untuk memperbaiki isi dokumen lingkungan DPLH sesuai dengan substansi dan kriteria.

j. Jika isi dokumen lingkungan DPLH sudah sesuai dengan substansi dan kriteria, maka akan diterbitkan pengesahan dan izin lingkungan.

Izin adalah upaya prefentif sekaligus represif dalam artian izin sebagai upaya pencegahan kerusakan lingkungan serta sekaligus menjadi upaya penegakan hukum bilamana ditemukan ketidaksesuaian antara izin dan usaha dan/atau kegiatan yang dibuat oleh pemrakarsa. Kota Yogyakarta sendiri berkenaan dengan cara memperoleh izin adalah sebagai berikut:

1. penyusunan dokumen Amdal dan/atau Upaya Pengelolaan Lingkungan Hidup (UKL) dan Upaya Pemantauan Lingkungan Hidup (UPL)

2. Penilaian yang dilakukan oleh bidang PPDL

3. Permohonan dan penerbitan Izin Lingkungan

Dalam pasal 42 ayat (1) Peraturan Pemerintah Nomor 27 tahun 2012 tentang Izin Lingkungan bahwa prosedur yang harus dilakukan untuk memperoleh izin lingkungan dimulai dengan:

1. Permohonan izin lingkungan secara tertulis oleh penanggungjawab usaha dan/atau kegiatan selaku pemrakarsa kepada pejabat dalam hal ini Bidang Penataan dan Pengendalian Dampak Lingkungan Kota Yogyakarta. 
2. Permohonan izin diajukan bersamaan dengan pengajuan penilaian Rencana Pengelolaan Lingkungan Hidup dan Rencana Pemantauan Lingkungan Hidup atau pemeriksaan UKLUPL.

3. Permohonan tersebut harus dilengkapi dengan:
a. Formulir UKL-UPL
b. Dokumen Pendirian usaha dan/atau kegiatan
c. profil usaha dan/atau kegiatan.

Setelah hal tersebut di penuhi, Dinas Lingkungan Hidup akan melakukan evaluasi untuk meninjau usaha dan/kegiatan yang dilakukan oleh pemrakarsa apakah sudah berkesesuaian dengan izin yang telah dibuat. Setelah semua terpenuhi pihak Dinas Lingkungan Hidup memberikan surat izin untuk melakukan usaha dan/atau kegiatan kepada pemrakarsa.

Berkenaan dengan pemberian sanksi administratif Dinas Lingkungan Hidup Kota Yogyakarta membuat bidang Penataan, Pengkajian dan Pengembangan Kapasitas Lingkungan Hidup khususnya seksi Penataan dan Penegakan Hukum Lingkungan yang mempunyai tugas menertibkan usaha dan/atau kegiatan yang tidak sesuai dengan izin yang telah dia ajukan. Dinas terkait melakukan evaluasi setelah 6 bulan kegiatatn dan/atau usaha dijalankan untuk melihat secara langsung kesesuaian izin serta usaha dan/atau kegiattan yang dilakukan.

Dalam wawancara, peneliti menemukan bahwa upaya penegakan hukum yang dilakukan oleh Dinas Lingkungan Hidup Kota Yogyakarta cenderung melakukan pendekatan yang prefentif dibandingkan dengan represif. Hal ini dilakukan untuk membantu pengembangan usaha masyarakat dan mempermudah pengurusan izin yang ada di Kota Yogyakarta agar ekonomi masyarakat tidak tersendat oleh perizinan yang berbeli-belit.

Dalam wawancara bersama bapak Ir. Suyana, beliau menyebutkan bahwa jika ditemukannya ada kekeliruan dan ketidaksesuaian antara izin lingkungan dan penerapan dilapangan maka Dinas Lingkungan Hidup akan memberikan peringatan terhadap pemrakarsa dan pemrakarsa harus segera untuk memperbaiki kekeliruan yang telah dibuatnya. Apabila teguran belum juga di indahkan maka sanksi berupa pencabutatn izin usaha dan/atau kegiatan akan menjadi upaya terakhir yang diberikan oleh Dinas Lingkungan Hidup Kota Yogyakarta.

Dalam kasus Fave Hotel yang mengakibatkan puluhan sumur warga mengering akibat perebutan air tanah antara warga dan hotel, pemerintah Kota Yogyakarta melalui Dinas Lingkungan Hidup Kota Yogyakarta telah memberikan sanksi administratif kepada pihak terkait disebabkan kejadian tersebut serta membebankan ganti kerugian terhadap warga sekitar karena telah kekurangan air bersih. Pemerintah menurut Ir. Suyana mengupayakan kebijakan yang bisa menguntungkan kedua belahpihak serta lingkungan sekitar agar terjadi sinkronisasi antara masyarakat, pemrakarsa, dan lingkungan.

Dalam penegakan hukum administrasi pemerintah Kota Yogyakarta melalui Dinas Lingkungan Hidup tidak selalui menggunakan kebijakan yang bersifat Top Down tanpa melibatkkan masyarakat setempat. Ketertlibatan masyarakat penjadi penting dikarenakan usaha dan/atau kegiatan sering kali dilakukan ditengah pemukiman warga. Dinas Lingkungan Hidup sering kali bertanya kepada masyarakat terkait kedala atau masalah yang timbul akibat dari adanya usaha dan/atau kegiatan disekitarnya. Hal ini dilakukan agar pelaku usaha dan masyarakat serta lingkungan tidak terganggun ekosistem yang telah ada selama ini. Dalam izin 
yang dikeluarkan pun harus meminta persettujuan dari masyarakat setempat baik secara lisan maupun tulisan sebelum usah dan/kegiata dilaksanakan. Hal ini lebih memperkuat niat baik pelaku usaha atatu pemrakarsa kepada masyarakat dan sekaligus mencegah konflik sosial antara masyarakat dan pelaku usaha.

Menurut penelitian peneliti, metode pemberian sanksi administrasi yang dilakukan oleh Dinas Lingkungan Hidup Kota Yogyakarta melalui Bidang Penataan, Pengkajian dan Pengembangan Kapasitas Lingkungan Hidup, seksi Penataan dan Penegakan Hukum Lingkungan. adalah dengan pendekatan yang bisa menguntungkan lingkungan, pelaku usaha serta masyarakat. Pemerintah Kota Yogyakarta lebih mengedepankan aspek prefentif dari hukum administrasi lingkungan daripada aspek respensif.

\subsection{Kendala Dalam Penegakan Hukum Administrasi Dalam Hal Analisis Mengenai Dampak Lingkungan}

Sistem politik yang demokratis didasarkan pada kedaulatan rakyat. Dengan demikian, rakyat diasumsikan paling sedikit sama kuat atau lebih kuat daripada pemerintah. Bila pemerintah lebih kuat dari rakyat, biasanya yang terjadi adalah sistem pemerintahan yang otoriter. Jika pemerintahan yang lebih kuat dari rakyat ini menjalankan sistem politik yang demokratis, maka demokrasi ini menjadi sekedar demokrasi pinjaman. Bilamana pemerintah merasa kurang berkenan dengan demokrasi yang diberikan, dia dengan mudah bisa menariknya kembali. $^{14}$

Kebijakan yang ada selama ini, selalu bersifat Top Down tanpa melibatkkan masyarakat setempat. Sehingga sering kali kebijakan yang ada bukanlah hal yang dibutuhkan oleh masyarakat. Selanjutnya setelah program tersebut selesai, masyarakat juga tidak tahu fungsi dan manfaat serta keuntungannya. Akibatnya, bangunan, atau hasil dari program tersebut hanya terbengkalai begitu saja. Masyarakat juga tidak mau terlibat dalam pemeliharaannya. Oleh karena itu sudah selayaknya kebijakan saat ini harus dibalik menjadi kebijakan yang bersifat bottom up, yaitu dengan melibatkan masyakarat lokal dari mulai perencanaan, pelaksanaan dan pemeliharaan. Dengan sistem ini diharapkan program yang dilaksanakan benar-benar sesuai dengan kebutuhan atau dengan kondisi masyarakat. Tentu dengan melibatkan langsung mereka dalam perencanaan, pelaksanaan dan pemeliharaan, masyarakat akan merasa memiliki dan bertanggung jawab terhadap program.

Partisipasi masyarakat merupakan salah satu aspek yang penting untuk diperhatikan dalam hal penyelenggaraan Kajian Lingkungan Hidup Strategis. Sebagai sebuah proses yang sistematis, rangkaian proses penyelenggaraan Kajian Lingkungan Hidup Strategis sudah seharusnya dilakukan dengan pendekatan konsultatif-partisipatif..$^{15}$

Saat ini pengawasan dan pengendalian terhadap kerusakan lingkungan perlu melibatkan seluruh elemen mulai dari masyarakat, pelaku usaha, hingga ke pemerintah dengan tujuan yang sama yaitu untuk kesejahteraan bersama. Pemerintah tidak dapat melakukan suatu tindakan berkaitan dengan lingkungan tanpa melihat efek pembangunan tersebut terhadap masyarakat dan lingkungan, sehingga perlu komunikasi yang baik antar keduanya.

\footnotetext{
${ }^{14}$ Arif Budiman, 1996, Teori Negara (Negara, Kekuasaan, dan Ideologi), Jakarta, Gramedia, h. 39.

${ }^{15}$ R. Kemala Nababan, 2017, "Potensi PP KLHS Dalam Mengintegrasikan Pembangunan Berkelanjutan Dalam Penyusunan Kebijakan, Rencana, dan/atau Program”, Hukum Lingkungan Indonesia, Volume 3, Jakarta, h. 133-134.
} 
Peran serta masyarakat digunakan sebagai alat untuk mendapatkan masukan berupa informasi dalam proses pengambilan keputusan. Persepsi ini dilandasi oleh suatu pemikiran bahwa pemerintah dirancang untuk melayani masyarakat, sehingga pandangan dan preferensi dari masyarakat tersebut adalah masukan yang bernilai guna mewujudkan keputusan yang responsif.

Dalam wawancara yang ditemukan peneliti, pihak Dinas Lingkungan Hidup memaparkan kendala atau tantangan dalam hal penerbitan izin lingkungan yaitu:

a. Pemenuhan izin berdasarkan komitmen yang berkaitan dengan Izin Lingkungan, hingga saat ini masih dilaksanakan secara offline/manual di Dinas Lingkungan Hidup.

b. Peraturan Pemerintah RI No. 24 Tahun 2018: sistem OSS belum mengakomodir PermenLHK No. 102/2016 terkait DELH dan DPLH.

c. Adanya batasan waktu proses penerbitan izin lingkungan (contohnya: 10 hari untuk UKLUPL), maka Izin Lingkungan dengan komitmen yang diterbitkan akan efektif berlaku. Padahal Peraturan Pemerintah RI No. 24 Tahun 2018 tidak mengatur ketentuan persyaratan sosialisasi bagi warga sekitar yang terkena dampak dalam proses penilaian dokumen lingkungan (tidak sejalan dengan yang sudah diatur dalam Peraturan Walikota Yogyakarta No. 6 Tahun 2016 tentang Pedoman Tata Cara Pengajuan Dokumen Lingkungan Hidup \& Izin Lingkungan). Hal ini dapat memicu timbulnya konflik sosial antara pelaku usaha dengan warga sekitar yang terkena dampak.

d. Belum adanya menu pilihan dalam OSS terkait kapasitas kegiatan yang merupakan persyaratan dalam penapisan jenis dokumen lingkungan (termasuk kriteria berkomitmen/tidak berkomitmen). Sehingga pelaku usaha dapat memanipulasi data rencana kegiatan yang akan dilakukan (untuk menghindari kewajiban menyusun dokumen lingkungan: UKL-UPL maupun AMDAL).

e. Pemerintah Kota Yogyakarta telah melakukan moratorium terhadap izin usaha: Hotel Non Bintang 4-5, Swalayan waralaba, Penjualan minuman beralkohol, Diskotek/klab malam, Permainan ketangkasan, Karaoke, Panti pijat/shiatsu, dan sejenisnya. Dengan adanya OSS, izin usaha tersebut dapat terbit kembali di Kota Yogyakarta karena di menu pilihan tidak ada pengecualian untuk memilih kegiatan tsb (hal ini tidak sinkron dengan kebijakan lokal).

Selain hal tersebut, kendala juga sering datang dari pemrakarsa sendiri yaitu ketidak lengkapan berkas yang diajukan kepada Dinas Lingkungan Hidup Kota Yogyakarta. Hal ini menurut hasil wawancara dengan Bidang Penataan dan Pengendalian Dampak Lingkungan, bapak Feri Edi Sunantyo, SKM., MPH. menjelaskan bahwa ketidaktahuan masyarakat sering kali menjadi faktor yang menyebabkan ketidak lengkapannya izin usaha yang diajukan. Hal ini seringkali menjadi kendala sebab dalam pengurusanya membuat pemrakarsa harus berkoordinasi lebih jauh dengan Dinas Lingkungan Hidup Kota Yogyakarta.

Maka dari itu, pihak Dinas Lingkungan Hidup membuka pendampingan pembuatan perizinan Lingkungan untuk masyarakat agar lebih mudah dalam hal pengurusan usaha dan/atau kegiatan yang akan dilakukan oleh masyarakat. 


\section{Simpulan}

Penegakan hukum yang dilakukan oleh Dinas Lingkungan Hidup Kota Yogyakarta melalui Bidang Penataan, Pengkajian, dan Pengembangan Kapasitas Lingkungan Hidup seksi Penaatan dan Penegakan Hukum Lingkungan Hidup menggunakan pendekatan yang prefentif yaitu lebih mengedepankan upaya pencegahan daripada upaya penegakan hukum. Hal ini dilakukan untuk menjaga kestabilan ekonomi Kota Yogyakarta dan mempermudah perizinan pelaku usaha dan/atau kegiatan yang ada di Kota Yogyakarta. Berkaitan dengan kendala yang dialami Dinas Lingkungan Hidup Kota Yogyakarta adalah lebih kepada kendala yuridis yaitu peraturan yang terlalu banyak hingga membuat pelaku usaha/pemrakarsa mengalami kesulitan dalam pembuatan izin lingkungan.

\section{Daftar Pustaka}

\section{Buku}

Arif Budiman, 1996, Teori Negara (Negara, Kekuasaan, dan Ideologi), Jakarta, Gramedia Pustaka Utama.

Imam Supardi, 2003, Lingkungan Hidup dan Kelestariannya, Alumni, Bandung

Muchsan, 1981, Beberapa Catatan tentang Hukum Administrasi Negara ke Peradilan Administrasi Negara, Yogyakarta: Liberty

Mukhlish dan Mustafa Lutfi, 2010, Hukum Administrasi Lingkungan Kontemporer, Setara Press, Malang.

Mukti Fajar ND \& Yulianto Achmad, (2015), Dualisme Penelitian Hukum Normatif \& Empiris, Penerbit Pustaka Pelajar, Yogyakarta

N.H.T. Siahaan, 2009, Hukum Lingkungan, Pancuran Alam, Jakarta.

Hendra Nurtjahyo, 2004, Politik Hukum Tata Negara Indonesia, Pusat Studi Hukum Fakultas Hukum Universitas Indonesia, Jakarta.

Prajudi Atmosurdirjo, 1988, Hukum Administrasi Negara, Seri Pustaka ilmu Administrasi, Ghalia Indonesia, Jakarta.

Siti Sundari Rangkuti dan Suparto Wijoyo, 1996, Penegakan Hukum Lingkungan Administrasi, Fakultas Hukum Unair, Surabaya.

Soerjono Soekanto dan Mustafa Abdullah, 1980, Sosiologi Hukum dalam Masyarakat, Rajawali, Jakarta.

Usep Ranawijaya, 1983, Hukum Tata Negara Indonesia Dasar-dasarnya, Ghalia Indonesia, Jakarta.

\section{Peraturan Perundang-undangan}

Undang-Undang Nomor 32 Tahun 2009 tentang Perlindungan dan Pengelolaan Lingkungan Hidup.

Undang-Undang Nomor 23 Tahun 2014 tentang Pemerintahan Daerah 
Peraturan Daerah Daerah Istimewa Yogyakarta Nomor 2 Tahun 2010 tentang Tata Ruang Wilayah Povinsi Daerah Istimewa Yogyakarta Tahun 2009-2029

Peraturan Daerah Kota Yogyakarta Nomor 2 Tahun 2010 tentang Rencana Tata Ruang Wilayah Kota Yogyakarta.

Peraturan Walikota Nomor 6 Tahun 2016 tentang Pedoman Tata Cara Pengajuan Dokumen Lingkungan Hidup dan Izin Lingkungan

\section{Jurnal}

Arcaropeboka, R. A. (2018), "Peran Pemerintah Dalam Penegakan Hukum Lingkungan", Jurnal Ilmu Hukum Justicia SainsI, Vol 03 No 2, November 2018.

Dr. H. Rahyunir Rauf, M.Si, 2017, "Perubahan Kedudukan Kelurahan Dari Perangkat Daerah Menjadi Perangkat Kecamatan", WEDANA, Volume III, Nomor 1, Riau.

Edorita, W. (2013), "Peran Serta Masyarakat Terhadap Lingkungan Menurut UU No 32 Tahun 2009 tentang Perlindungan dan Pengelolaan Lingkungan Hidup", Jurnal Ilmu Hukum, Vol 4 No 1.

Fitria, 2015, "Penegakan Hukum Administrasi Terhadap Analisis Mengenai Dampak Lingkungan(AMDAL) Berdasarkan Undang-Undang 32 Tahun 2009 Di Kota Jambi”, Jurnal Ilmu Hukum, Fakultas Hukum Univertsitas Jambi.

Grahat Nagara, 2017, "Perkembangan Sanksi Administratif Dalam Penguatan Perlindungan Lingkungan Terkait Eksploitasi Sumber Daya Alam (Studi Kasus : Sektor Perkebunan, Pertambangan, dan Kehutanan)", Jurnal Hukum Lingkungan Indonesia, Volume 3 Issue 2, Jakarta Selatan.

Komang Trie Krisnasari, 2013, "Penerapan Undang-Undang Nomor 32 Tahun 2009 Tentang Perlindungan Dan Pengelolaan Lingkungan Hidup Dalam Upaya Penegakan Hukum Lingkungan Di Indonesia", Kertha Semaya Vol. 01, No. 03, Bali.

Kusdarini, E, 2005, "Arti Penting dan Implementasi Hukum Perijinan dalam Bidang Lingkungan Hidup di Indonesia", Jurnal Civics, Yogyakarta.

Mifta Farid, Antikowati,\& Rosita Indrayati, 2017, "Kewenangan Pemerintah Daerah dan Partisipasi Masyarakat dalam Pengelolaan Potensi Daerah", Journal Lentera Hukum, Vol. 4, No. 2, Jember.

Muchammad Taufiq, 2011, "Kedudukan dan Prosedur AMDAL dalam Pengelolaan Lingkngan Hidup", Jurnal WIGA No, 2088-0944. Lumajang.

R. Kemala Nababan, 2017, "Potensi PP KLHS Dalam Mengintegrasikan Pembangunan Berkelanjutan Dalam Penyusunan Kebijakan, Rencana, dan/atau Program", Hukum Lingkungan Indonesia, Volume 3, Jakarta. 


\section{Internet}

Eko Nugroho, "Potensi dan Permasalahan Kota Yogyakarta", https://www.academia.edu/7494529/Potensi_dan_Permasalahan_Kota_Yogyakarta?auto= download. Diakses pada 10 Juni 2019 pukul 20.00 WIB.

Nasrullah, 2015, "Hukum Lingkungan", http://repository.umy.ac.id/bitstream/handle/123456789/4060/HUKUM\%20LINGKUNG AN.pdf?sequence=1\&isAllowed=y, diakses pada 1 Juli 2020, pukul 20.30 WIB.q

Mawa Kresna, 2017, "Resiko dan Nasib Buruk Pembangungan Hotel di Yogyakarta", https://tirto.id/risiko-dan-nasib-buruk-pembangunan-hotel-di-yogyakarta-bkWg. Diakses pada 10 Juni 2019 pukul 20.10 WIB.

Redaksi, "14 Dampak Pembangunan Terhadap Lingkungan yang Wajib Diketahui", https://materiips.com/dampak-pembangunan-terhadap-lingkungan, Diakses pada 10 Juli 2019, pukul 13.31 WIB. 